\title{
Caring about medullary anesthesia in Saimiri sciureus: the conus medullaris topography
}

\author{
ANA R. LIMA ${ }^{1}$, EMERSON T. FIORETTO ${ }^{2}$, RODRIGO F. FONTES ${ }^{2}$, \\ ALINE A. IMBELONI ${ }^{3}$, JOSÉ A.P.C. MUNIZ ${ }^{3}$ and ÉRIKA BRANCO ${ }^{1}$ \\ ${ }^{1}$ Universidade Federal Rural da Amazônia (UFRA), Instituto de Saúde e Produção Animal - (ISPA), \\ Faculdade de Medicina Veterinária, Avenida Perimetral, 2501, 66077-901 Belém, PA, Brasil \\ ${ }^{2}$ Universidade Federal de Sergipe (UFS), Avenida Marechal Rondon, s/n, Jardim Rosa Elze, \\ Cidade Universitária Professor José Aloísio de Campos, São Cristovão, 49100-000 Aracajú, SE, Brasil \\ ${ }^{3}$ Centro Nacional de Primatas (CENP), Instituto Evandro Chagas (IEC), Secretaria de Vigilância em Saúde, \\ Ministério da Saúde, BR 316, Km 7, Caixa Postal 44, 67030-000 Ananindeua, PA, Brasil \\ Manuscript received on February 10, 2011; accepted for publication on April 28, 2011
}

\begin{abstract}
Saimiri sciureus is a New World non-human primate (NHP) that inhabits Brazilian rain forests. Surgical interventions in wild NHPs can be considered common both for experimental studies procedures and corrective procedures for endangered species. Among various anesthetic procedures, the epidural anesthesia or blockades, depending on the surgical procedure, might be considered elective for wild monkeys, mostly based on its safeness, efficiency and nontime consuming characteristics. However its safeness would be limiting because of the spinal cord arrangement. Notwithstanding the available former studies on New World NHP anatomy, the description of the medullar cone of Saimiri sciureus is still scarce. Therefore, we believe that the better understanding the medullar cone of Saimiri sciureus would contribute to improve the applicability of epidural procedures in the species. Vertebrae architecture of Saimiri sciureus was composed by 9 lumbar, 3 sacral and 18 coccygeal vertebrae, and the medullar cone measured about $3.3 \mathrm{~cm}$. We can conclude that the conus medullaris in Saimiri sciureus is situated more caudally in comparison to other species.
\end{abstract}

Key words: anatomy, conus medullaris, epidural anaesthesia, Saimiri sciureus.

\section{INTRODUCTION}

Saimiri sciureus is a New World non-human primate (NHP) that inhabits Brazilian rain forests and whose life differs from Old NHPs because it is entirely developed on trees, being rare its ground descending (Coimbra Filho 1982, Rylands et al. 2000). Surgical interventions in wild NHPs can be considered common both for experimental studies procedures and corrective procedures for endangered species.

Among various anesthetic procedures, the epidural anesthesia or blockades, depending on the surgical procedure, might be considered elective for wild mon-

Correspondence to: Ana Rita de Lima

E-mail: vetlima@uol.com.br keys, mostly based on its safeness, efficiency and nontime consuming characteristics. However its safeness would be limiting because of the spinal cord arrangement (Dyce et al. 2004, Fantoni and Cortopassi 2002, Hopkins 1935). Meanwhile, it has been considered that small volumes of anesthetic applied on the virtual space between the yellow ligament and duramater near the medullary cone would be safer and prevent injuries over the spinal cord (Hilbery 1992), which emphasizes the necessity of a full control of the sight of application and its regular anatomy. Epidural anesthesia presents innumerable applications, as well as it might be very welcome as an adjuvant procedure to promote postoperative analgesia that would prevent or diminishes the animal stress thus improving recovery. 
Notwithstanding the available former studies on New World NHP anatomy, the description of the medullar cone of $S$. sciureus is still scarce. Therefore, we believe that the better understanding the medullar cone of $S$. sciureus would contribute to improve the applicability of epidural procedures in the specie.

\section{MATERIALS AND METHODS}

Animals that have deceased from natural causes were donated by the National Center of Primates (Cenp). All procedures were carried out according to the international practices for animal use and care under the control of an internal committee of the Evandro Chagas Institute, Ananindeua, PA, under authorization number $008 / 2010$. Two male and two female specimens were perfused and immersed in a $10 \%$ aqueous formaldehyde solution for fixation. The dissection procedure was carried out by a dorsal median line incision and skin removal from the thorax to the tail basis. Epiaxial musculature and vertebral arcs were also removed in order to reveal the medulla and its covering tissues. Medullar cone was dissected and measured with the aid of a caliper rule. Veterinary Medicine Anatomical Nomina (Schaller 1999) illustrations were followed to name the structures. InStat 3 software was used for statistical analyses.

\section{RESULTS}

Vertebrae architecture was composed by 9 lumbar, 3 sacral and 18 coccygeal vertebrae (Fig. 1). Three welldefined structures were visualized at the lombar sacral region: the lumbar intumescences (L6-L7/L8), the conus medullaris and the cauda equine (Fig. 2). Despite the gender, the medullar cone of $S$. sciureus measured about $3.3 \mathrm{~cm}$ (Table I) and was divided into two regions: a) a base extending along the $7^{\text {th }}$ or $8^{\text {th }}$ lumbar vertebrae (L7 or L8), and b) an apex situated between the $3^{\text {rd }}$ vertebrae sacrales (S3) and the $1^{\text {st }}$ vertebrae coccygeae (Cc1).

\section{DISCUSSION}

The caudal portion of the spinal cord of S. sciureus was presented as a cylindrical and prolonged mass, being slightly flattened at the lumbar intumescence. The conus medullaris was observed caudally to the lumbar intumescence being similar to the one of other mammals (Erhart 1992, Getty 1975). This region is a site of epidural anesthesia when anesthetic drugs are applied in a virtual space under duramater to promote analgesia of waist and pelvic limbs.

The length of the conus medullaris in Saimiri sciureus was relatively small (about $3.30 \mathrm{~cm}$ ) when compared to other mammals as the rabbit, $4.51 \mathrm{~cm}$ (Santos 1996); Equus caballus (embryo) 4.20 cm (Manzan et al. 2003); marine wolf (Arctocephalus australis) $4.40 \mathrm{~cm}$ (Machado et al. 2003); Moorish cat (Herpailurus yagouaroundi) $5 \mathrm{~cm}$ (Carvalho et al. 2003); giant brazilian otter (Pteronura brasiliensis) $5.5 \mathrm{~cm}$ (Machado et al. 2009a); paca (Agouti paca) 5.20 to $5.80 \mathrm{~cm}$ (Scavone et al. 2007) and maned wolf (Chrysocyon brachyurus) $6.5 \mathrm{~cm}$ length (Machado et al. 2002). On the other hand, its length is similar to goat (Capra aegagrus) $3.44 \mathrm{~cm}$ (Santos et al. 2001), and relatively larger than nutria (Myocastor coypus), $2 \mathrm{~cm}$ (Machado et al. 2009b). Conus medullaris is an important structure for epidural anesthesia procedures (Barry 1956, Bruni and Zimmerl 1977, Dyce et al. 2004, Evans and De Lahunta 1994, Fletcher 1979, Getty 1975, Habel 1951, Hopkins 1935, Santiago et al. 1990, Schwarze and Schröder 1972, Seiferle 1951), but the specific values cannot be exactly considered in wild animals, being necessary the description for each species of interest.

Although data about conus medullaris in primates are scarce we could compare our results to the descriptions of Machado et al. who described the conus medullaris base of sagui (Calitrix jacus jacus) between vertebrae L2 and L4 (Machado et al. 1992) of the maned wolf (Chrysocyon brachyurus) between vertebrae L3 and L6 (Machado et al. 2002), in marine wolf (Arctocephalus australis) between vertebrae T5 and T7 (Machado et al. 2003), of rabbits (Oryctolagus cuniculus) between vertebrae L6 and L7 (Santos et al. 1999), of paca (Agouti paca) between vertebrae L5 and L7 (Scavone et al. 2007), the horse between vertebrae L5 and L6 (Santos 1996), and in domestic cats (Felis catus) at level of L6 (Câmara-Filho et al. 1998). Concerning the apex, in buffalo (Bubalus bubalis) it is located at S3 (Rao 1976); in sheep (Ovis aries), at the S2 (Rao 1990), in domestic cats (Felis catus) at S1 (CâmaraFilho et al. 1998), in impala (Lama glama) in rabbit 


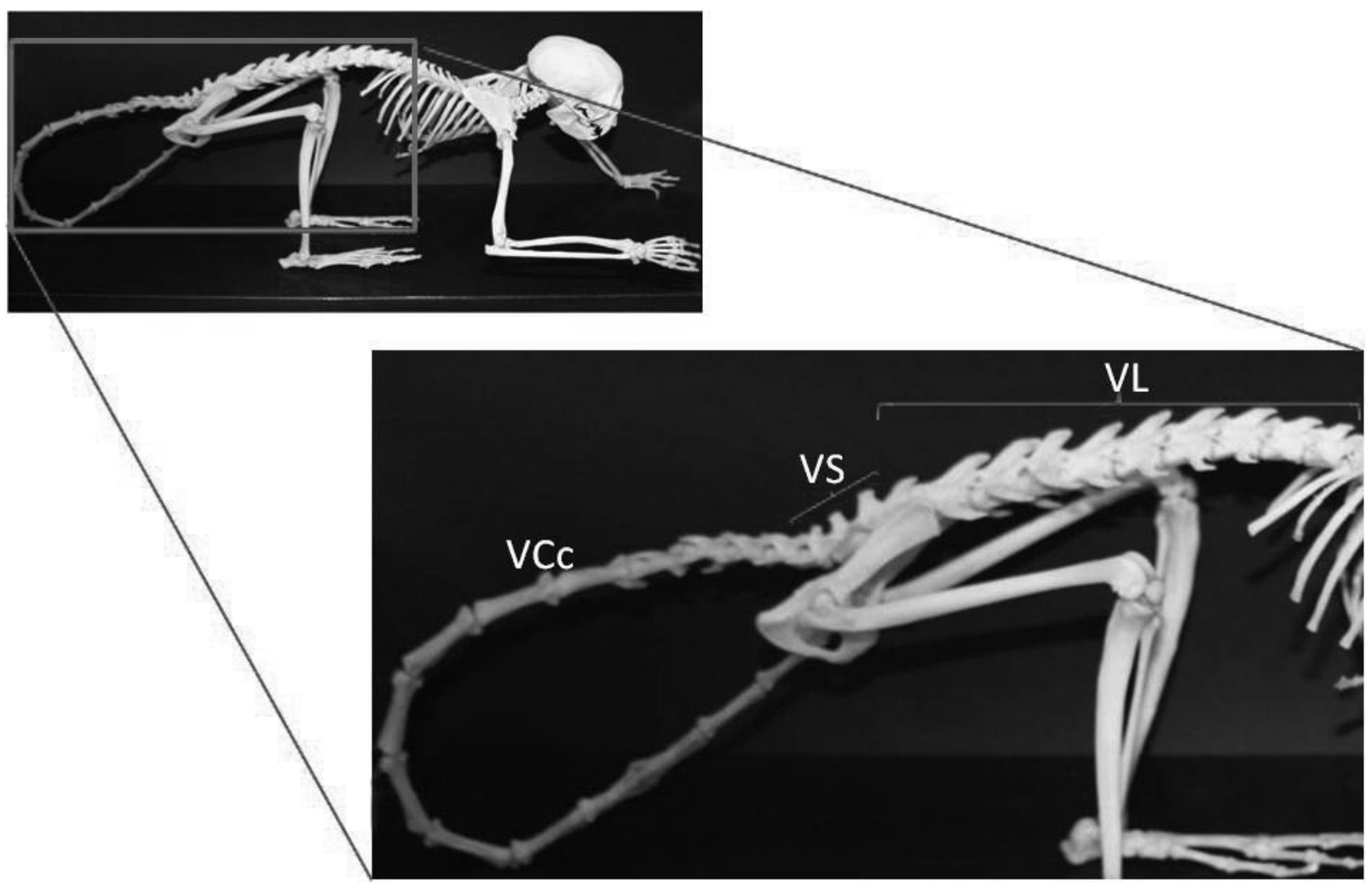

Fig. 1 - Photograph of the skeleton of Saimiri sciureus. In the detail lumbo-sacrale region of the vertebral column show the vertebrae lumbales (VL), vertebrae sacrales (VS) and vertebrae coccygeae (VCc).

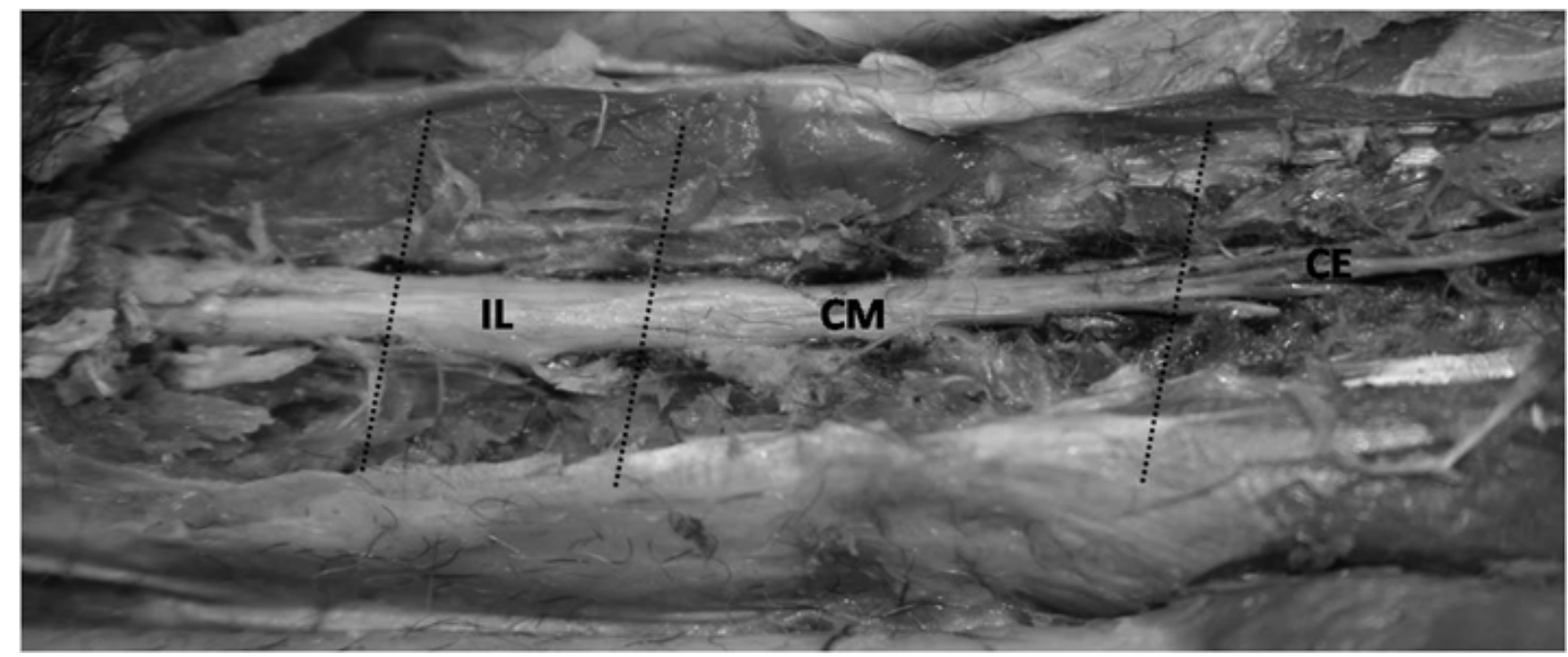

Fig. 2 - Photograph of the dorsal view of the conus medullaris from Saimiri sciureus evidencing lumbar intumescences (IL), conus medullaris $(\mathrm{CM})$ and cauda equine (CE). 
TABLE I

Values of length of the conus medullaris and abrangency of the described structures.

\begin{tabular}{c|c|c|c}
\hline & $\begin{array}{c}\text { Cone length } \\
(\mathrm{cm})\end{array}$ & $\begin{array}{c}\text { Abrangency } \\
\text { (conus medullaris) }\end{array}$ & $\begin{array}{c}\text { Abrangency } \\
\text { (lumbar intumescences) }\end{array}$ \\
\hline Female 1 & 3.4 & L8-Cc1 & L7-L8 \\
Female 2 & 3.2 & L7-Cc1 & L6-L7 \\
Female medium & 3.3 & & \\
Standard deviation & 0.14 & & L7-L8 \\
Male 1 & 2.9 & L8-Cc1 & L6-L7 \\
Male 2 & 3.8 & L8-S3 & \\
Male medium & 3.3 & & \\
Standard deviation & 0.63 & & \\
\hline
\end{tabular}

(Oryctolagus cuniculus) (Santos et al. 1999), in paca (Agouti paca) (Scavone et al. 2007), in marine wolf (Machado et al. 2003), and in man at the level of L1-L2 (Willians et al. 1995).

We can conclude that the conus medullaris in Saimiri sciureus is situated more caudally in comparison to other species. Its base is situated between L7-L8, and the apex between $\mathrm{S} 3-\mathrm{Cc} 1$, which would provide a suggestive site for epidural anesthesia procedures regarding analgesia to waist and pelvic limbs in this species.

\section{ACKNOWLEDGMENTS}

We wish to thank National Center of Primates (Cenp) for the animals used in this research.

\section{RESUMO}

Saimiri sciureus é um primata não humano do novo mundo (NHP) que habita as florestas úmidas brasileiras. Intervenções cirúrgicas em NHP selvagens podem ser consideradas comuns em estudos experimentais ou procedimentos corretivos para espécies em perigo. Entre os vários procedimentos anestésicos, a anestesia ou bloqueio epidural depende do procedimento cirúrgico a ser realizado, podendo ser considerada eletiva para macacos selvagens baseada na segurança, eficiência e pouco tempo consumido, entretanto sua segurança pode estar limitada devido ao arranjo da medula espinhal. Apesar de existirem estudos anatômicos disponíveis de NHP a descrição do cone medular do Saimiri sciureus permanece escassa. Portanto, nós acreditamos que o melhor entendimento a respeito do cone medular do Saimiri sciureus pode contribuir para melhorar a aplicabilidade de procedimentos epidurais nesta espécie. A arquitetura vertebral do Saimiri sciureus é com- posta por 9 vértebras lombares, 3 sacrais e 18 coccígeas e o cone medular apresentou tamanho médio de $3,3 \mathrm{~cm}$. Podemos concluir que o cone medular Saimiri sciureus está situado mais caudalmente em comparação com outras espécies.

Palavras-chave: anatomia, cone medular, anestesia epidural, Saimiri sciureus.

\section{REFERENCES}

BARRY A. 1956. A quantitative study of praenatal changes in angulation of spinal nerves. Anat Rec 126: 97-109.

BRUni AC AND ZimmerL U. 1977. Anatomia degli animali domestici. Milano: Francesco Vallardi, 736 p.

CÂmara-Filho JA, Rodrigues M AND Silveira R. 1998. Determinação morfológica do cone medular espinhal no espaço da primeira vértebra sacral. Rev Cent Cien Med EFF 2: 55-59.

CARVAlho SFM, Santos ALQ, AVILA Junior RH, Andrade MB, Magalhães LM, Moraes FM AND RIBEIRO PIR. 2003. Topografia do cone medular em um gato mourisco, Herpailurus yagouaroundi (Severtzow, 1858) (Felidae). Arch Vet Science 8: 35-38.

CoIMBra FilHo AF. 1982. Distribuição geográfica, ecologia, extinção e preservação de platirrinos. In: SALDANHA PH. Genética comparada de primatas brasileiros. Sociedade Brasileira de Genética, p. 83-103.

Dyce KM, SACK WO And Wensing CJG. 2004. Tratado de anatomia veterinária. Rio de Janeiro: Guanabara Koogan, 813 p.

ERHART EA. 1992. Elementos de anatomia humana. São Paulo: Atheneu, $280 \mathrm{p}$.

Evans HE AND De Lahunta A. 1994. Guia para a dissecação do cão. Rio de Janeiro: Guanabara Koogan, $206 \mathrm{p}$. 
FAnTONi DT AND CORTOPASsi SRG. 2002. Anestesia em cães e gatos. São Paulo: Roca, 389 p.

FLETCHER TF. 1979. Spinal cord and meninges. In: EvANS HE AND CHRISTENSEN GC (Eds), Miller's anatomy of the dog. Philadelphia: W.B. Saunders Company, 1181 p.

GetTy R. 1975. Sisson and Grossman's. The anatomy of the domestic animals. Philadelphia: W.B. Saunders Company, $1211 \mathrm{p}$.

HABEL RE. 1951. Guide to the dissection of the Cow. New York: Cornell Cooperative Society, 375 p.

HILBERY ADR. 1992. Manual de anestesia de los pequeños animals. España: Acribia Zaragoza, 154 p.

HopkINS GS. 1935. The correlation of anatomy and epidural anesthesia in domestic mammals. Cornell Veterinarian 25: $263-270$.

Machado GV, CAL JA AND BIRCK AJ. 2009b. Topografia do cone medular no ratão-do-banhado (Myocastor coypus Molina, 1782 - Rodentia: Mammalia). Rev Biotemas 22: $117-120$.

Machado GV, Lesnau GG and Birck AJ. 2003. Topografia do cone medular no lobo-marinho (Arctocephalus australis Zimmermann, 1803). Arq Cien Vet Zool 6: 1114.

Machado GV, Riella ACM And Liegel SR. 1992. Esqueletopia do cone medular em Calitrix jacus jacus. Anais do XXII Congresso Brasileiro de Medicina Veterinária, Curitiba, Brasil, $56 \mathrm{p}$.

MACHAdo GV, Rosas FCW And LAZZARIni SM. 2009a. Topografia do cone medular na ariranha (Pteronura brasiliensis Zimmermann, 1780). Cien Anim Bras 10: 301-305.

Machado VM, Fonseca CC, Neves Mtd, Paula TAR AND BENJAMIN LA. 2002. Topografia do cone medular no lobo-guará. Rev Bras Cien Vet 9: 107-109.

Manzan RM, CARneiro WP, Moraes FM, SANTos AlQ, Silva F, SEverino RS And DRUMmond SS. 2003. Esqueletopia do cone medular em fetos de equinos. Vet Notícias 9: 18.
RAO GS. 1976. A study of spinal cord segments in the Indian Buffalo. J Anat Soc India 16: 43-50.

RAO GS. 1990. Anatomical studies on the ovine spinal cord. Anat Anz 171: 261-264.

Rylands AB, Schneider H, Langguth A, MitterMeier RA, Groves CP AND Rodriguez-LunA E. 2000. An assessment of the diversity of New World primates. Neot Primates 8: 61-93.

SAntiago W, Machado GV, Vizioli VP AND BARRA PHM. 1990. Esqueletopia do cone medular em caprinos mestiços. Anais do IX Congresso Mineiro de Medicina Veterinária, Belo Horizonte, Brasil, 107 p.

SAntos ALQ. 1996. Topografia do cone medular em equinos (Equus caballus). In: XV CONGRESSO PANAMERICANO DE CIÊNCIAS VETERINÁRIAS, Campo Grande, Brasil, 15 p.

SAntos ALQ, Lima EMM And SAntana MIS. 1999. Length of spinal cord and topography of conus medullaris in rabbit (Oryctolagus cuniculus). Biosci J 15: 45-62.

SAntos ALQ, Lima EMM AND SANTANA MIS. 2001. Topografia do cone medular em caprinos da raça Saanen. Arq Cien Vet Zool 4: 25-29.

ScAVone ARF, Guimarẽes GC, Rodrigues VHV, SASAHARA THC AND MACHAdo MRF. 2007. Topografia do cone medular da paca (Agouti paca, Linnaeus - 1766). Braz J Vet Res An Sci 44: 53-57.

SCHALLER O. 1999. Nomenclatura anatômica veterinária ilustrada. São Paulo: Manole, 614 p.

SCHWARZE E AND SCHRÖDER L. 1972. Compendio de anatomía veterinária. Zaragoza: Acribia, 247 p.

SEIFERLE E. 1951. On the topography of the equine and bovine spinal cord. Z Anat 110: 731-784.

Willians PL, WARWick L, DYSON M AND BANNister LH. 1995. Gray Anatomia. Rio de Janeiro: Guanabara Koogan, 1147 p. 